\title{
Carbon stock in topsoil, standing floor litter and above ground biomass in Tectona grandis plantation 10-years after establishment in Ile-Ife, Southwestern Nigeria
}

\author{
Anthony Ifechukude ODIWE*, Rofiat Adedoyin ADEWUMI, Abibat Afolakemi ALIMI \\ and Olugbenga OGUNSANWO
}

Department of Botany, Obafemi Awolowo University, Ile-Ife, Osun State, Nigeria.

${ }^{*}$ Corresponding author, E-mail: aiodiwe@oauife.edu.ng; Tel.: +2347034394721

\begin{abstract}
This paper provides information on carbon stock at the habitat level in the above ground biomass $(\mathrm{ABG})$, standing floor litter and soils in a 10 year-old Tectona grandis plantation following restoration of a degraded secondary forest at Obafemi Awolowo University, Ile-Ife Nigeria. Four sample plots $25 \mathrm{~m} \mathrm{x} 25 \mathrm{~m}$, two in Tectona grandis plantation and two in a nearby degraded secondary forest were studied. Soil samples were randomly collected at 0-20 cm and bulk density determined. Standing floor litter was randomly collected at five points every three months for one year, sorted into different litter components. Soil and standing floor litters carbon concentration and $\mathrm{C}$ stock were determined. Above ground biomass $(\mathrm{ABG})$ and carbon stock were significantly ( $\mathrm{p}=0.003$ and $\mathrm{p}=0.0001$ ) higher in the plantation, the order is $\mathrm{ABG}>$ soil $>$ standing floor leaf litter > standing floor wood litter. Soil C stock varies from $10.47 \mathrm{t} \mathrm{ha}^{-1}$ in the plantation to $10.58 \mathrm{t} \mathrm{ha}^{-1} \mathrm{C}$ in the forest. Above ground biomass, standing leaf and wood litter were estimated as 18.26-5.81, 0.49-0.36, 0.06$0.08 \mathrm{t} \mathrm{ha}^{-1} \mathrm{C}$, respectively (plantation to secondary forest). Reforestation after 10 years has increased $\mathrm{C}$ stocks by $45 \%$ in $\mathrm{ABG}$ in the plantations.

(C) 2012 International Formulae Group. All rights reserved.
\end{abstract}

Keywords: Carbon stock, degraded forest, plantation, reforestation, standing litters.

\section{INTRODUCTION}

Forests form an active carbon pool that accounts for 60 per cent of carbon storage in the earth's land surface (Wilson and Daff, 2003). Forests contain about $80 \%$ of global terrestrial above-ground carbon stocks (biomass), and play an important role in the global carbon cycle (Houghton, 2005). Tropical forests have also been reported to be a strong carbon sink (Stephens et al., 2007) and contributed about one fifth of total anthropogenic $\mathrm{CO}_{2}$ emissions to the atmosphere through tropical deforestation (Houghton et al., 2007). Despite the above mentioned importance of forest, the forest is being continuously destroyed at a very fast and alarming rate (Pimm et al., 1995). More than $50 \%$ of the tree cover has disappeared due to human activities mainly through forest vegetation removal (Kaewkrom et al., 2011). This forest destruction in particular deforestation, is driven by a wide variety of human activities including farming, population growth, bush burning, fuel wood 
collection, commercial purposes, illegal logging, urbanization, transmigration programs, road construction, mining, and hydropower development (Kaewkrom et al., 2011). Management of forests as carbon reservoirs have become an important component of broader environmental practices aimed at the protection of biological, soil, water, and air resources. It has been pointed out by many studies that reduction in forest harvesting, skilful management of forest and agro forestry systems, as well as restoration and management of degraded forest lands has potential for the conservation and sequestration of carbon (Dixon et al., 1993). Afforestation is one of the viable options of carbon sequestration in terrestrial ecosystem (Fang et al., 2001). It is recognized as major sink for carbon as well as accumulating carbon above ground, thus making significant contributions to soil carbon even in dry lands (Silver et al., 2000). Depending on the type of vegetation, terrestrial ecosystems could be a source or a sink for atmospheric $\mathrm{CO}_{2}$ (Guo and Gifford, 2002). Forest and plantation ecosystems management practices can play a significant role in climate change mitigation by sequestering carbon through photosynthesis (Watson et al., 2000; Guariguata et al., 2008; Strassburg et al., 2009). Several studies have been conducted to explore the effect of plantations on ecosystems carbon and nitrogen stock. Post and Kwon (2000) reported that although there is much variability in rates of carbon addition, conditions generally favor increases of soil organic carbon when cultivated soils are converted to perennial vegetation, such as forest or grassland. Guo and Gifford (2002) summarized data from 74 studies that analyzed land uses change on soil carbon stocks and found that when cropland changed to plantation and secondary forest, soil carbon stocks increased by $18 \%$ and $53 \%$, respectively, making them to conclude that cropland conversion to forest will result in partial to complete recovery in soil carbon. Redondo-Brenes and Montagnini (2006) have also pointed out that even though in reforestation projects carbon sequestration may be a secondary objective, the use of mixed plantations with species of different rotation times may allow the system to retain the carbon for longer periods of time than in a monoculture and that species in mixed plantings had higher values of carbon sequestration than the pure plantings in two out of three groups of plantations. Zheng et al. (2008) in their study on the dynamics of ecosystem carbon allocation as affected by different forest management practices, measured the above-and belowground biomass accumulation over 14 years, as well as the tissue carbon concentrations of trees in three monospecific plantations and reported that natural restoration is a superior approach for increasing the carbon storage potential in the hilly red soil region in reforestation projects compared to plantations. Berthrong et al. (2009) found a significant decrease in soil organic $\mathrm{C}$ and $\mathrm{N}$ with Pinus afforestation, but not with other species (Eucalyptus, angiosperm, conifers), and based on their results and a review of other literature, it was suggested that proper site preparation and sustainable harvest practices, such as avoiding the removal or burning of harvest residue, could minimize the impact of afforestation on soils. As part of the effort to re-claim and restore part of the destroyed rich natural forest at the Obafemi Awolowo University Estate, Ile-Ife, Nigeria, wide-scale planting of Tectona grandis species among other tree crops species was embarked upon ten years ago (2001) across the University estate. The establishment of Tectona grandis plantation looks successful going by the stand of trees that thrived within the University estate, however, no conscious effort has been undertaken to assess the impact of the reforestation activities ten years after on both soil and aboveground biomass carbon stock in this ecosystem. The ten year period was chosen so that we can have gradual information on the impact of afforestation on the nutrients level including carbon content and also to serve as a basis for future comparisons. This study therefore specifically 
evaluated the carbon stock in the soil, standing floor litter and in the aboveground biomass as affected by reforestation with Tectona grandis after 10 years of planting. This was done with the intention of providing information on the benefit or otherwise of reforestation with Tectona grandis plant on a degraded soil about carbon stock in the soil, standing floor litter and in the above ground biomass in other to increase the understanding of carbon fixation and storage in plantation ecosystems in Nigeria.

\section{MATERIALS AND METHODS Study Area}

The study was conducted at the Obafemi Awolowo University Estate, Ile-Ife, Osun state, Nigeria. Ile-Ife is located on Latitude $\mathrm{N} 07^{0} 31.311^{\prime}$ and Longitude E $004^{0}$ 30.983 ' and the elevation of Ife ranges from $215 \mathrm{~m}$ to $457 \mathrm{~m}$ above sea level (Hall, 1969). The study sites lies between Latitude $\mathrm{N}$ $007^{0} 32$ ' and Longitude E $004^{0} 31^{\prime}$ while the elevation ranges from $243 \mathrm{~m}$ to $274 \mathrm{~m}$ above the sea level. The study sites are shown in figure 1 . The climate of the area is a tropical type with two prominent seasons, the rainy and the dry season. The dry season is short, usually lasting 4 months from November to March and the longer rainy season prevails during the remaining months. The annual rainfall average $1413 \mathrm{mmyr}^{-1}$ in a 5-year survey and it showed two peaks, one in July and the other in September, the mean annual temperature range from $22.5{ }^{0} \mathrm{C}$ to $31.4{ }^{0} \mathrm{C}$ (Duncan, 1974). The soil of the area is derived from material of old basement complex which is made up of granitic metamorphosed sedimentary rock (Hall, 1969). Five major soil types have been recognized in this area: inselberg soils, Hill creep soils, and sedimentary non-skeletal soils, drift soils, alluvial deposits (Hall, 1969). The soil has been classified as lixisols and utisols (FAO/UNESCO, 1974). The original vegetation of Ile-Ife is lowland rainforest as climax vegetation (Keay, 1959). White (1983) described the vegetation as the GuineaCongolian drier forest type. Most of the original lowland rain forests have been massively destroyed leaving remnant of secondary forest scattered around. Tree crops plantations like Theobroma cacao, Cola nitida, Tectona grandis, and Elaeis guineensis are now common around the area. The Tectona grandis plantation was established in remnant of degraded secondary forest and farmland within the area of the University estate. The seedlings were first raised in the black plastic polyethylene bags at the nursery and later transplanted to the field. The seedlings were planted in August, 2001 (raining month) in the field with a spacing of $2.44 \times 2.44 \mathrm{~m}$. Intensive weeding was done during early establishment of the plantation ( 1-2 years), since the plantation is a light demanding species and its growth development is reduced sharply under poor light conditions and the plantation was never thinned.

\section{Data collection and laboratory analysis Sampling procedure}

Four sample plots each of $25 \mathrm{~m}$ x $25 \mathrm{~m}$ were used for this study, two plots in the Tectona grandis plantation and the other two in a nearby degraded secondary forest. The plots were laid out with a measuring tape and demarcated by narrow cut-lines.

\section{Soil sample collections}

Soil samples were randomly collected at five points within each plot at the depth of 0-20 cm using soil auger. The first round of soil sampling took place during the dry season in March, 2011 and the second one in August (rainy season). We concentrated our sampling on the surface soil and standing floor because it was speculated that any differences among the plantation and the degraded forest would be most evident in these locations. Each soil sample was air-dried, passed through a $2 \mathrm{~mm}$ sieve, and analyzed for total organic carbon at International Institute for Tropical Agriculture (IITA), Ibadan using automated and semiautomated methods for soil described by Tel and Rao (1982). Soil bulk density measurements are needed to convert soil carbon concentration i.e., mass carbon per unit 
mass soil into inventories or storage i.e., mass per unit area. The bulk density was estimated by inserting a fixed-volume steel ring into the soil at five randomly located points in each plot at $0-20 \mathrm{~cm}$. The rings were excavated; soil samples were removed from them, dried at $105^{\circ} \mathrm{C}$ for 48 hours, and then weighed (Blake and Hartge, 1986). The mean bulk densities from these collected soil samples per depth were used to estimate soil carbon stock at $0-20 \mathrm{~cm}$ in the degraded secondary forest and plantation.

\section{Standing floor litter Collection}

To quantify standing floor mass, standing floor litter were randomly collected at five points using a $50 \mathrm{~cm}$ x $50 \mathrm{~cm}$ quadrat size, all the standing floor litter inside the quadrat was collected. This was separated into leaves, wood, reproductive organs (flowers and fruits) and thrash (those that cannot be easily classified into any of the above components), and oven dried at $60{ }^{\circ} \mathrm{C}$ weighed and grounded with three replicates per plot. The ground leaf and wood standing floor litter components were analyzed to determine organic carbon at International Institute for Tropical Agriculture (IITA), Ibadan using automated and semi-automated methods for soil analysis described by Tel and Rao (1982). The reproductive and trash components were discarded because they were very small.

\section{Estimation of above ground biomass and carbon stock}

Aboveground biomass (AGB) and its existing carbon stock were estimated in both Tectona grandis plantations and the degraded secondary forest. All trees with diameter at breast height $(\mathrm{DBH})$ greater than $0.1 \mathrm{~m}$ were enumerated, measured, and classified. Ravi's altimeter was used to measure tree height and AGB for the tree species strata was estimated from measured diameter at breast height (DBH) and tree height using a generalized tree biomass regression for the specific precipitation zone (Brown, 1997):

$$
\mathrm{Y}=\exp \left(-3.1141+0.9719 \ln \left(\mathrm{DBH}^{2} \times \mathrm{H}\right)\right.
$$

Where $\mathrm{Y}$ is the aboveground biomass in $\mathrm{kg}$; $\mathrm{DBH}$, diameter at breast height in $\mathrm{cm}$;

$\mathrm{H}$ is the height of tree in $\mathrm{m}$ and this was converted to $\mathrm{t} \mathrm{ha}^{-1}$ by multiplying by 0.001 .

Standing floor litter stocks were calculated in both the plantation and degraded secondary forest by multiplying the concentrations of total $\mathrm{C}$ with the corresponding dry weights and converted to $\mathrm{t}$ $\mathrm{ha}^{-1}$. Soil C stock was computed by multiplying the concentration of total $\mathrm{C}$ by bulk density and the corresponding depth at which the sampling was done. Carbon stock of AGB was calculated by the conversion factor 0.5 (Atjay et al., 1979; Brown, 1997; Brown and Lugo, 1982; Dixon et al., 1994).

\section{Statistical Analysis}

The statistical significant differences in carbon stock in above ground biomass, soil, and standing floor litter were compared between the Tectona grandis plantation and the degraded forest using a T-test of an unequal samples size and the significant means were separated using Tukey's pair-wise comparison. The statistical package used is SPSS software, Model 13.0 and the level of testing significance was set at $0.05 \%$.

\section{RESULTS}

In the present investigation, AGB analysis using $\mathrm{DBH}$ and height of trees yielded different size classes of trees. In general, DBH of tree in class size 31-60 cm (70\%) was found dominant in the plantation, while $0-30 \mathrm{~cm}(80 \%)$ was dominant in the degraded secondary forest (Figure 2). Tree height recorded is in the range of 6.7 to $9.1 \mathrm{~m}$ and 3.1 to $10.5 \mathrm{~m}$ in the plantation and the degraded secondary forest respectively. Aboveground biomass ranged from $38.33 \mathrm{t} \mathrm{ha}^{-}$ ${ }^{1}$ in the plantation vegetation to $16.19 \mathrm{t} \mathrm{ha}^{-1}$ in the degraded secondary forest. Carbon stock in AGB varied between $19.16 \mathrm{t} \mathrm{C} \mathrm{ha}^{-1}$ in the plantation to $8.10 \mathrm{t} \mathrm{C} \mathrm{ha}^{-1}$ (Table 1). Carbon held within total aboveground biomass is higher in the plantation compared with the degraded secondary forest (Table 1). 


\section{Standing floor leaf litter nutrients}

The results showed that carbon stock in the standing floor leaf litter was significantly $(\mathrm{p}=0.030)$ different, carbon stock being lower $\left(0.361 \mathrm{t} \mathrm{ha}^{-1}\right)$ in the Tectona grandis plantation compared to $\left(0.467 \mathrm{t} \mathrm{ha}^{-1}\right)$ in the degraded secondary forest (Table 2). The same trend was observed in the standing floor wood litter, where $\mathrm{C}$ stock was significantly $(\mathrm{p}=0.002)$ lower in the plantation with $0.06 \mathrm{t} \mathrm{ha}^{-1}$ compared to the degraded forest with $0.08 \mathrm{t}$ ha ${ }^{-1}$ (Table 2).

\section{Soil nutrients}

Result from this study showed that the bulk density values ranges from $0.74 \mathrm{~g} \mathrm{~cm}^{-3}$ in the plantation to $0.77 \mathrm{~g} \mathrm{~cm}^{-3}$ in the degraded secondary forest and there was no significant $(\mathrm{p}=0.330)$ difference in bulk density between the two areas. Soil carbon stock was not significantly different $(\mathrm{p}=0.26)$ (Table 3$)$. Generally it is clear from this study that carbon stock recorded is in the order of above ground biomass > soil > leaf litter > wood litter.

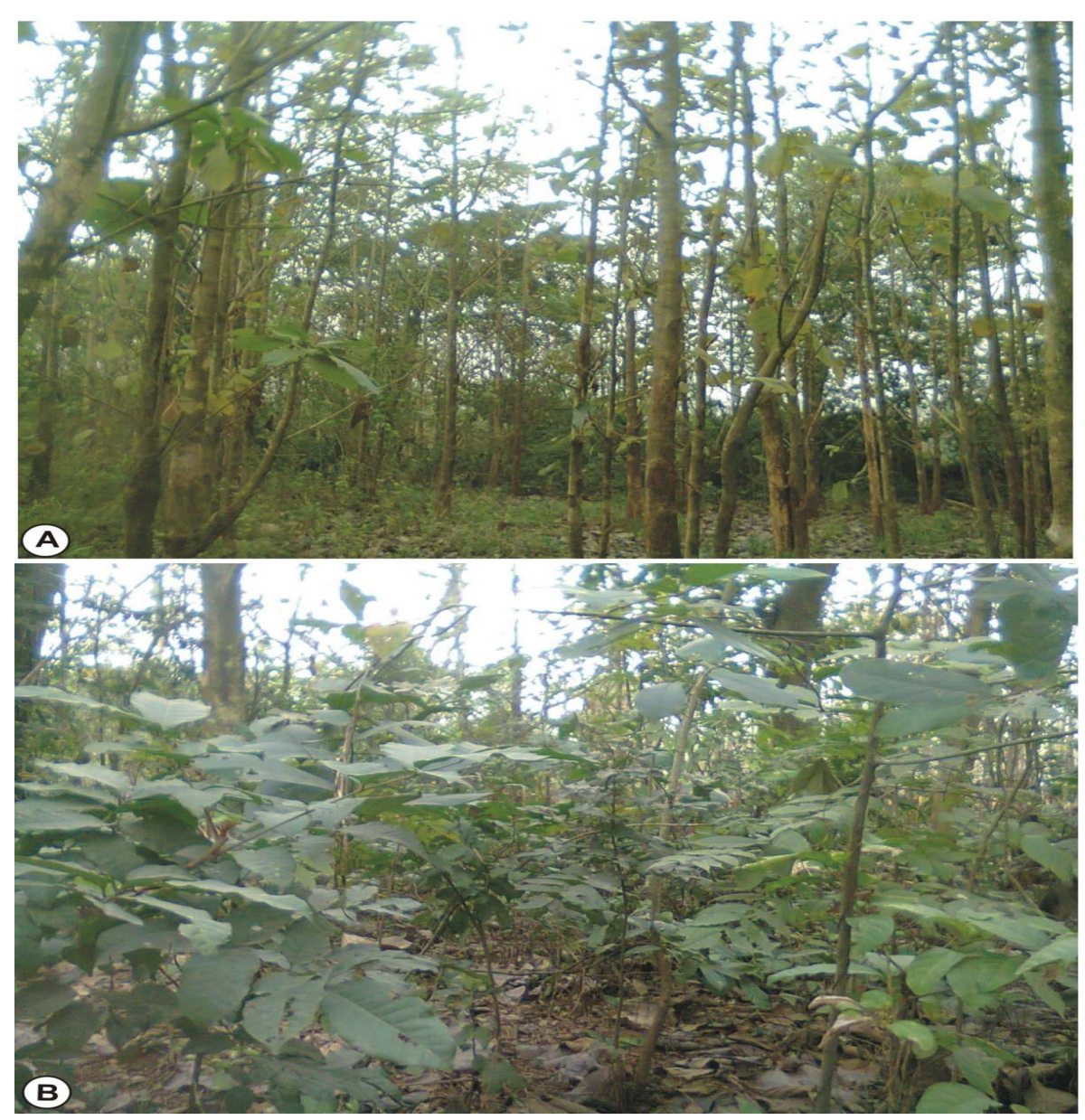

Figure 1: shows $(\mathrm{A})=$ Tectona grandis plantation $;(\mathrm{B})=$ Degraded secondary forest in Ile-Ife, Southwestern Nigeria. 


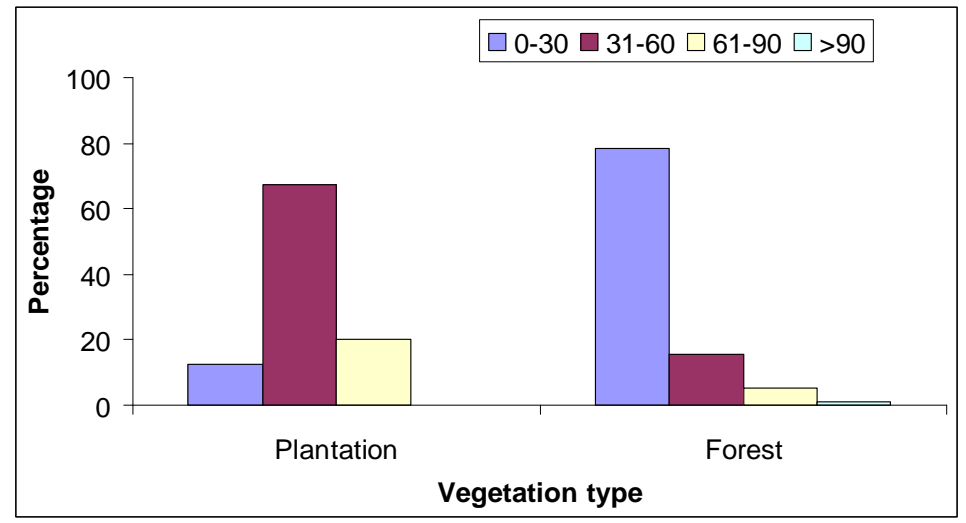

Figure 2: Distribution of above ground biomass (percentage) with respect to diameter at breast height across the plantation and the degraded forest.

Table 1: Above ground biomass and carbon stock in Tectona grandis plantations and degraded secondary forest ( \pm Standard error of the mean), n: number of trees in the study sites.

\begin{tabular}{|c|c|c|c|c|}
\hline \multirow[b]{2}{*}{ Vegetation type } & \multicolumn{3}{|c|}{ Above ground biomass $\mathrm{t} \mathrm{ha}^{-1}$} & \multirow{2}{*}{$\begin{array}{c}\text { Total carbon } \\
\text { stock t ha }\end{array}$} \\
\hline & Maximum & Minimum & $\begin{array}{l}\text { Mean } \pm \text { std. } \\
\text { error }\end{array}$ & \\
\hline Plantation & 62.07 & 21.74 & $38.33 \pm 0.40$ & $20.08 \pm 0.20$ \\
\hline Re-growth forest & 20.92 & 3.71 & $16.19 \pm 0.09$ & $8.10 \pm 0.05$ \\
\hline $\begin{array}{l}\text { Difference between } \\
\text { the sites }\end{array}$ & 41.15 & 18.03 & 22.14 & 11.98 \\
\hline p-value & & & & $0.0003 * * *$ \\
\hline
\end{tabular}

Table 2: Standing floor litter carbon stock in the Tectona grandis plantation and degraded secondary forest. Results are presented as mean and standard error of the mean.

\begin{tabular}{|c|c|c|c|c|c|}
\hline Stanc & $\begin{array}{l}\text { floor carbon } \\
\text { stock }\end{array}$ & Plantation & $\begin{array}{l}\text { Re-growth } \\
\text { Forest }\end{array}$ & $\begin{array}{c}\text { Difference between the } \\
\text { sites }\end{array}$ & p-value \\
\hline \multirow{3}{*}{$\begin{array}{l}\text { Leaf } \\
\text { litter }\end{array}$} & Maximum & 0.102 & 0.213 & 0.11 & \\
\hline & Minimum & 0.467 & 0.73 & 0.26 & \\
\hline & $\begin{array}{l}\text { Mean } \pm \text { std. } \\
\quad \text { error }\end{array}$ & $0.361 \pm 0.03$ & $0.467 \pm 0.04$ & 0.11 & $0.002 * *$ \\
\hline \multirow{3}{*}{$\begin{array}{l}\text { Wood } \\
\text { litter }\end{array}$} & Maximum & 0.012 & 0.09 & 0.08 & \\
\hline & Minimum & 0.075 & 0.169 & 0.094 & \\
\hline & $\begin{array}{l}\text { Mean } \pm \text { std } \\
\quad \text { error }\end{array}$ & $0.059 \pm 0.01$ & $0.079 \pm 0.02$ & 0.02 & $0.030 *$ \\
\hline
\end{tabular}


Table 3: Soil carbon stock measured across the study sites. Results are presented as mean and standard error of the mean.

\begin{tabular}{lllll}
\hline Soil carbon stock & Maximum & Minimum & Mean \pm std. error & p-value \\
\hline Plantation & 15.30 & 3.56 & 10.47 & $\mathrm{P}=0.26$ \\
Re-growth forest & 12.36 & 2.78 & 10.58 & \\
\hline Significant differences between plantation and degraded secondary forest are indicated in bold at $0.05 \%$ alpha level.
\end{tabular}

\section{DISCUSSION}

\section{Above ground biomass and carbon stock}

Disturbances can disrupt the $\mathrm{C}$ cycle through direct effects on tree biomass, the age-class distribution of the forest shifts to younger stands containing less $\mathrm{C}$ as observed in the degraded forest where the Dbh $0-30 \mathrm{~cm}$ was the dominant size class (Lindenmayer and Franklin, 2000) and soil organic matter decomposition (Didham, 1998) and therefore, leading to reduction in $\mathrm{C}$ stocks. The result of lower size $(0-30 \mathrm{~cm})$ class being dominant in the degraded forest illustrates the important contribution of small tree to above ground biomass and the lower biomass densities might indicate that the site is highly disturbed, and is just undergoing succession process. The dominant of $31-60 \mathrm{~cm}$ girth size in the plantation could be because the trees were planted at the same time, they are thus uniform and the trees have not been harvested since establishment. It must be noted that this study is a bold attempt to estimate carbon stock in tropical vegetation in Nigeria using data from a 10 year-old Tectona grandis plantation and a degraded secondary forest. Since, data on above ground biomass and carbon stock are not generally available in Nigeria, our result was compared to data from other parts of the world. The aboveground biomass recorded in this study sites $(38.33 \mathrm{t}$ $\mathrm{ha}^{-1}$ in plantation and $16.19 \mathrm{t} \mathrm{ha}^{-1}$ in the degraded sites) was smaller compared with other studies. Brown et al. (1989) estimated aboveground biomass to be an average of 215 $\mathrm{Mg} \mathrm{ha}{ }^{-1}$ and $192 \mathrm{Mg} \mathrm{ha}^{-1}$ for undisturbed tropical forests of Asia and the world, respectively. Brown et al. (1991) showed that tropical forests in South and Southeast Asia that appeared to have experienced little human disturbance had aboveground biomass of more than 350-400 Mg ha' ${ }^{-1}$, compared with 194$270 \mathrm{Mg} \mathrm{ha}^{-1}$ for forests that were exposed to human disturbance. Results from this study showed that above ground biomass increased at the rate of $3.8 \mathrm{t} \mathrm{ha}^{-1} \mathrm{Yr}^{-1}$ in a ten year period and is lower than the value of $6.2 \mathrm{t} \mathrm{ha}^{-1} \mathrm{yr}^{-1}$ reported by Silver et al., (2000) in their study in tropical forests in the first 20 years after afforestation. Nilsson and Schopfhauser (1995) reported the rates of aboveground carbon accumulation to be 6.4-10.0 t ha $1 \mathrm{yr}^{-1}$ in tropical Asia, Africa, and Latin America. The values of carbon stock recorded in this study (plantation $20.08 \mathrm{t} \mathrm{C} \mathrm{ha}^{-1}$ and the degraded forest $8.10 \mathrm{t} \mathrm{C} \mathrm{ha}^{-1}$ ) are generally lower than the values found in other systems in Africa e.g. $152 \mathrm{Mg} \mathrm{C} \mathrm{ha}{ }^{-1}$ for cocoa agroforestry in south Cameroon (Duguma et al., 2001); 66-88 $\mathrm{Mg} \mathrm{C} \mathrm{ha}^{-1}$ in Oil palm and 248-264 Mg C ha ${ }^{-1}$ rubber plantations in Cameroon (Egbe et al., 2012); and in other parts of the world: $150 \mathrm{Mg} \mathrm{ha}^{-1}$ (82-242) in Spain (Balboa-Murias et al., 2006); an average of $135 \mathrm{Mg} \mathrm{ha}^{-1}$ in Pinus radiata and $99 \mathrm{Mg} \mathrm{ha}^{-1}$ in Pinus pinaster reported by Balboa-Murias et al. (2004). The values from our study are however within the range recorded in Costa Rica (12.4-79.1 $\mathrm{Mg} \mathrm{C} \mathrm{ha}^{-1}$ ) by Redondo-Brenes (2007) and in India (7.80298.56 t C ha $^{-1}$ ) by Mohanraj et al. (2011). Generally one must exercise caution in comparing the study results because of differences in the forest types, site types, management systems, monitoring, the methodology and model equation used in 
different studies (Masera et al., 2003; Chave et al., 2005; Mani and Parthasarathy, 2007). Redondo-Brenes (2007) reported that fastgrowing species accumulate more carbon in the first stages of their life span, while the high specific gravity of slower-growing species accumulates more carbon in the longterm. Above ground biomass and consequently carbon stock has been reported to be influenced in any particular region by factors such as climate, solar radiation, and disturbance, age of forest, species composition, and soil characteristics (Birdsey and Heath, 1995). Dutcã et al., (2009) has also pointed out that the rate of carbon storage in forest biomass depends on tree growth rate: the more biomass is added through photosynthesis the more carbon is stored. It is clear from this study that species composition, disturbance and age of the vegetation are the main factors influencing carbon stock especially in the above ground biomass. The surface leaf litter $\mathrm{C}$ stock recorded in this study ( 0.36 to $\left.0.47 \mathrm{tha}^{-1}\right)$ is comparable to the results of 0.16 to $3.26 \mathrm{t} \mathrm{ha}^{-1}$ obtained by Mohanraj et al. (2011) in India. The standing floor wood litter carbon stock (0.06 to 0.08 t C $\mathrm{ha}^{-1}$ ) recorded in this study is also not completely different to the values of 0.0006 to $0.0977 \mathrm{t} \mathrm{ha}^{-1}$ reported in Coarse Wood Debris (CWD) carbon stock in India. Nilsson and Schopfhauser (1995) have reported that the carbon stored in litter was estimated to be about $0.5 \mathrm{t} \mathrm{ha}^{-1}$ for boreal forests, $2.8 \mathrm{t} \mathrm{ha}^{-1}$ for temperate forests and $3.7 \mathrm{t} \mathrm{ha}^{-1}$ in tropical forests.

\section{Changes in Soil Carbon}

The value of $10.47-10.58 \mathrm{t} \mathrm{ha}^{-1}$ soil $\mathrm{C}$ recorded in this study is very low compared with the values of $79.06-95.10 \mathrm{t} \mathrm{C} \mathrm{ha}^{-1}$ carbon stock reported by Anikwe (2010) at the sites representing natural forest, artificial forest and artificial grassland ecosystems in Nigeria. They reported that continuously cropped and conventionally tilled soils were reported to have about $70 \%$ lower carbon stock (19.78-28.22 t C ha $\left.{ }^{-1}\right)$. The lower values recorded in this study might be related to age of the vegetations, ours is 10 and theirs is 45 years. Our results of lower carbon stock in the degraded forest is consistent with the findings of Lai (2005), who reported that the destruction of the primary forest in the past, for use as agricultural land, or other uses released and increased carbon into the atmosphere thereby reducing the amount of $\mathrm{C}$ that is stored in the soil. Land use change, have also been reported to deplete the soil carbon stock. He pointed out that degraded agricultural soils have lower SOC stock than their potential capacity. Important factors like previous land use, the climate and the type of forest installed (Post and Kwon, 2000) have been pointed out to influence the change in soil carbon. Guo and Gifford (2002) showed that planting broadleaf trees into pasture had little effect on soil carbon stock whereas conifer trees reduce soil carbon stocks by $12 \%$. They also reported that climatic factors plays a role, area of lower rainfall areas

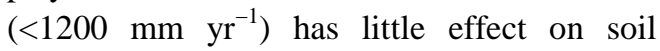
carbon stock while area of higher rainfall (1500 $\mathrm{mm} \mathrm{yr}^{-1}$ ) had significantly reduced soil carbon stock. The dynamics of soil carbon has also been reported to be a function of the type of land use change (Guo and Gifford, 2002). The highest loss in SOC was found to occur in area where pasture land has been converted to agricultural crop while the lowest impact on SOC change occurred in change in land use from pasture to plantation and plantation to pasture. It has also been pointed out that when pastures are converted to conifer plantations, SOC declines, while when they are converted to either broadleaf tree plantations or naturally regenerated secondary forest, SOC is unaffected. It is important to note that data collected from tropical environments are used in estimating total world carbon sequestration potential because differences in edaphoclimatic conditions and soil management practices influence the storage of carbon in the soil, therefore effort must be geared toward making some of these data available. 


\section{Conclusion}

From our findings, re-forestation with Tectona grandis after ten years had no significant effect on soil carbon stock, however, it has a considerable effect on standing floor litter and above ground biomass carbon stock. This study has provided some little information on the carbon stock and above ground biomass in tropical area of Nigeria. The Tectona grandis species may be selected for establishment and conserve carbon stock especially in above ground biomass and forest floor litter in the shortterm.It is clear that the age of the vegetation and site disturbance influenced carbon stock in the above ground biomass and the standing floor litter. A lot of work still needs to be carried out to determine the impact of age and level of disturbance (deforestation, fire, etc.) on above ground biomass and carbon stock in order to better our understanding on carbon sequestration and release to the atmosphere in the face of global climate change in Nigeria. The shifts from fallow (degraded forest) to plantations can also generate other ecological problems which could results from soil disturbance in the process of plantation establishment. There is the need to continue to monitor the impact of reforestation since reforestation of this site occurred only ten years ago-a short period compared with the age of mature forest. Further changes may still be expected to occur in the next few years as it might takes longer years for any considerable changes especially in carbon soil pool

\section{ACKNOWLEDGEMENTS}

The authors acknowledge and thank Mr. Raimi Idris of the Institute of Ecology and Environmental Studies, Obafemi Awolowo University for his assistance in the field during data collection.

\section{REFERENCES}

Anikwe MAN. 2010. Carbon storage in soils of Southeastern Nigeria under different management practices. Carbon Balance and Management. 5(5): 1-7.

Atjay GL, Ketner P, Duvignead P. 1979. Terrestrial primary production and phytomass. In The global Carbon Cycle, Bolin B, Degens ET, Kempe S (eds). Wiley and Sons: New-York, USA; 129182.

Balboa-Murias MA, Rojo A, Álvarez JG, Merino A. 2006. Carbon and nutrient stocks in mature Quercus robur L. stands in NW Spain. American For. Sci., 63: 557-565

Balboa MA, Rodríguez-Soalleiro R, ÁlvarezGonzález JG, Merino A. 2004. Temporal variations and distribution of $\mathrm{C}$ stocks in above-ground tree biomass of Pinus radiata and Pinus pinaster pure stands under different silvicultural alternatives, International IUFRO Conference on sustainable harvest scenarios in forest management, Talé, Slovaquia.

Berthrong ST, Jobbagy EG, Jackson RB. 2009. A global meta-analysis of soil exchangeable cations, $\mathrm{Ph}$, Carbon and Nitrogen with afforestation. Ecology Applications 19: 2228-2241.

Birdsey RA, Health LS. 1995. Carbon changes in U.S Forest. In Productivity of America's Forests and Climate Change Joyce, L. A. (ed) Forest Service, Rocky Mountain Forest and Range Experiment Station, Forth Collins: USA CO.; 56-70.

Blake GR, Hartge KH. 1986. Bulk density. In Methods of Soil Analysis, part 1. Physical and Mineralogical Methods, Klute A (ed). Agronomy Monograph no. 9 (2nd edn). Soil Science Society of America; 363-375.

Brown S. 1997. Estimating Biomass and Biomass Change of Tropical Forests. A Primer No.134. FAO. Forest Resources Assessment Publication: Roma; 55.

Brown S, Lugo AE. 1982. The storage and production of organic matter in tropical forests and their role in the global carbon cycle. Biotropica, 14: 161-187. 
Brown S, Gillespie AJR, Lugo AE. 1989. Biomass estimation methods for tropical forests with applications to forest inventory data. For. Sci., 35(4): 381-902.

Brown S, Gillespie AJR, Lugo AE. 1991 Biomass of tropical forests of South and Southeast Asia. Canadian Journal of Forestry Research, 21: 111-117.

Chave J, Andalo C, Brown S, Cairns MA Chambers JQ, Eamus D, Fölster H Fromard F, Higuchi N, Kira T, Lescure JP, Nelson BW, Ogawa H, Puig H, Riéra B, Yamakura T. 2005. Tree allometry and improved estimation of carbon stocks and balance in tropical forest. Oecologia, 145: 87-99.

Didham RK. 1998. Altered leaf-litter decomposition rates in tropical forest fragments, Oecologia, 116: 397- 406.

Dixon RK, Winjum JK, Schroeder PE. 1993. Conservation and sequestration of Carbon: The potential of forest and agroforest management practices. Global Environmental Change, 3: 159-171.

Dixon RK, Brown S, Houghton RA, Solomon AM, Trexler MC. 1994. Carbon pools and flux of global forest ecosystem. Science, 263: 185-190.

Duguma B, Gockowski J, Bakala J. 2001. Smallholder Cacao (Theobroma cacao Linn.) cultivation in agroforesrty systems of West and Central Africa: challenges and opportunities. Agrofor. System, 51: 177-188.

Duncan ER. 1974. Weather Information from the University of Ife. University press: Ile-Ife.

Dutcã I, Abrudan IV, Bluddea V. 2009. The impact of a forestation on carbon storage - a review. University of Brasov. Bulletin of the Transilvania, 2(51): 13-18.

Egbe AE, Tabot PT, Fonge BA, Bechem E. 2012. Simulation of the impacts of three management regimes on carbon sinks in rubber and oil palm plantation ecosystems of South-Western Cameroon. Journal of Ecology and the Natural Envoronment, 4(6): 154-162.
Fang JY, Chen AP, Peng CH, Zhao SQ, Ci LO. 2001. Changes in forest biomass carbon storage in China between 1949 and 1998. Science, 292: 2320-2322.

FAO/UNESCO. 1974. World soil classification. In Legend to Soil Map of the World (vol 1). UNESCO: Paris.

Guariguata MR, Cornelius JP, Locatelli B, Forner C, Sanchez-Azofeifa GA. 2008. Mitigation needs adaptation: Tropical forestry and climate change. Mitig. Adapt. Strategy Global Change, 13: 793808.

Guo LB, Gifford RM. 2002. Soil carbon stocks and land use change: a metaanalysis. Global Change Biology, 8: 345360.

Hall JB. 1969. The Vegetation of Ile-Ife. University of the Ife Herbarium Bulletin 1.

Houghton RA. 2005. Aboveground Forest Biomass and the Global Carbon Balance. Global Change Biology, 11(6): 945-958.

Houghton RA, Butman D, Bunn AG, O N Krankina ON, Schlesinger P, Stone TA. 2007. Mapping Russian forest biomass with data from satellites and forest inventories. Environ. Res. Lett., 2: 1-7.

Kaewkrom P, Kaewkla N, Thumnikkapong S, Punsang S. 2011. Evaluation of carbon storage in soil and plant biomass of Primary and Secondary mixed deciduous forests in the lower northern part of Thailand. African Journal of Environmental Science and Technology, 5(1): 8-14.

Keay RWJ. 1959 An Outline of the Nigerian Vegetation $\left(3^{\text {rd }}\right.$ edn). Government Printer: Lagos, Nigeria.

Lai R 2005. Forest Soils and Carbon Sequestration. Forest Ecology and Management, 220(1-3): 242-258.

Lindenmayer DB, Franklin JF, 2000. Conserving Forest Biodiversity: a Comprehensive Multiscale Approach. Insland Press: Washington.

Mani S, Parthasarathy N. 2007. Above-ground biomass estimation in ten tropical dry 
evergreen forest sites of peninsular India. Biomass and Bioenergy, 31: 284-290.

Masera OR, Garza-Caligaris JF, Kanninen M, Karjalainen T, Liski J, Nabuurs GJ, Pussinen A, de Jong BHJ, Mohren GMJ. 2003. Modeling carbon sequestration in afforestation, agroforestry and forest management projects: the CO2FIX V.2 approach. Ecological Modelling, 164: 177-199.

Mohanraj R, Saravanan J, Dhanakumar S. 2011. Carbon stock in Kolli forests, Eastern Ghats (India) with emphasis on above ground biomass, litter, woody debris and soils. Forest-Biogeosciences and Forestry, 4: 61-65.

Nilsson S, Schopfhauser W. 1995. The carbon sequestration potential of a global afforestation program. Climatic Change, 30: 267-293.

Pimm SL, Russell GJ, Gittleman JL, Brooks TM. 1995. The future of biodiversity. Science. 269: 347-350.

Post W, Kwon K. 2000. Soil carbon sequestration and land-use change: processes and potential. Global Change Biology, 6: 317-28.

Redondo-Brenes A. 2007. Growth, carbon sequestration, and management of native tree plantations in humid regions of Costa Rica. New Forests, 34: 253-268.

Redondo-Brenes A, Montagnini F. 2006. Growth, productivity, aboveground biomass, and carbon sequestration of pure and mixed native tree plantations in the Caribbean lowlands of Costa Rica. Forest Ecology and Management, 232: 168-178.

Silver WL, Neff J, McGroddy M, Veldkamp E, Keller M., Cosme R. 2000. Effects of soil texture on belowground carbon and nutrient storage in a lowland Amazonian forest. Ecosystems, 3: 193-209.
Strassburg B, Turner RK, Fisher B, Schaeffer R, Lovett A. 2009. Reducing emissions from deforestation- The combined incentives mechanism and empirical simulation. Global Environ. Change, 19: 265-278.

Stephens BB, Gurney KR, Tans PP, Sweeney C, Peters W, Bruhwiler L, Ciais P, Ramonet M, Bousquet P, Nakazawa T, Aoki S, Machida $\mathrm{T}$, Inoue $\mathrm{G}$, Vinnichenko N, Lloyd J, Jordan A, Heimann M, Shibistova O, Langenfelds RL, Steele LP, Francey RJ, Denning AS. 2007. Weak northern and strong tropical land carbon uptake from vertical profiles of atmospheric CO2. Science, 22(316): 1732-1735.

Tel DA, Rao, PV. 1982. Automated and Semiautomated Methods for Soil and Plant Analysis No. 7. International Institute of Tropical Agriculture Oyo Road, PMB 5320: Ibadan, Nigeria.

Watson RT, Noble IR, Bolin B, Ravindranath NH, Verado DJ, Dokken DJ. 2000. Land Use, Land-Use Change and Forestry. Cambridge University press: Cambridge.

White F. 1983. The Vegetation of Africaa Descriptive Memoir to Vegetation Map Africa. UNESCO: Paris.

Wilson BRSA, Daff JT. 2003. Australia's state of the forests report. Department of Agriculture, Fisheries and Forestry, Govt. of Australia.

Zheng H, Ouyang Z, Xu W, Wang X, Miao H, Li X, Yuxin, Y. 2008. Variation of carbon storage by different reforestation types in the hilly red soil region of southern China. Forest Ecology and Management, 255: 1113-1121. 